\title{
Analysis of Security Challenges along Commercial Water Routes of Bayelsa State, Nigeria
}

\author{
${ }^{1}$ Odeh A., ${ }^{2}$ Ogbuji E.C. and ${ }^{* 1}$ Emenike G.C. \\ ${ }^{1}$ Centre for Logistics and Transport Studies, University of Port Harcourt, Port Harcourt, Nigeria \\ ${ }^{2}$ Department of Maritime Studies, Maritime University, Okerenkoko, Delta State, Nigeria
}

\begin{abstract}
The study examined the security challenges along the commercial water routes of Bayelsa State, Nigeria. A total of 320 copies of a questionnaire on the operators and passengers in the study area to elicit information from the operators and passengers in the eight selected Bayelsa waterfronts. Both descriptive and inferential statistics were used for the data analysis. Findings showed that the Nembe-Brass route, Oporoma-Yenagoa route, Yenagoa-Brass route and Ogbia-Brass route are commercially viable routes making them enticing routes both for transportation and pirates and robbers attacks. Furthermore, Also, piracy/sea robbery, cultism, smuggling, kidnapping and illegal oil bunkering were identified as the major types of security challenges that are common in the Bayelsa waterways. However, evening and night periods experience more attacks than all other periods of the day. Unemployment, underdevelopment, illiteracy, lack of adequate security and poverty, cost and availability of fuel, lack of navigation aid, decrease in water level, multi-designated Nembe-Brass route, Oporoma-Yenagoa route, Yenagoa-Brass route and Ogbia-Brass route are commercially viable routes making them enticing routes both for transportation and pirates and robbers attacks authorities were the main causes of insecurity on Bayelsa waterways. It is recommended among others that the commercial water transport routes in Bayelsa State should be constantly dredged intermittently by State government to enable bigger ships to ply the routes thereby enabling more commercial activities; both Federal, State, Local governments and Inland waterways transport regulatory bodies should make available navigational aid and adequate security along the routes to avert any variety of security challenges.
\end{abstract}

Keywords: Security, Commercial Water routes, Water Transport, Bayelsa, Nigeria.

\section{INTRODUCTION}

The Niger Delta has witnessed an unprecedented level of insecurity in its waters (as lakes, canals, rivers etc). This has threatened national security and has prompted huge allocation of the national budget to security (Achumba et al., 2013); this produces piracy/sea robbery, pilferage, kidnapping, weapon proliferation, illegal bunkering and environmental pollution along inland waters routes in Bayelsa State and it has become difficult for vessels/boat owners, administrators, operators and users to do seaborne activities and commerce.

Bayelsa State has on many accounts and times recorded various security related issues along its water routes and have created several security concerns and challenges for water transport users. This has negative trade effect on a regional, national and international scale. The noted security challenges among these are; piracy/sea robbery, kidnapping and "bunkering," (illicit tapping, theft, and sale of oil in big quantities) are committed on inland water routes of Bayelsa State. These crimes committed usually impact negatively on human with regards to robbing both traders and passengers of their goods and valuables, kidnapping for money ransom and illegal bunkering for money gotten from illegal sale of crude oil leading to environment pollution; which both have economic and environmental implication. Another one is the youth restiveness and militancy necessitated by the zeal to run the oil-rich areas which has also contributed negatively to the swell in security challenges along water routes; and has given rise capital flight since most oil companies shut down their activities and leaving the state (Okonkwo et al, 2015).. Environmental contaminations of rivers are a common sight due to pollution from illegal bunkering affecting the socio-economic livelihood of riverine communities' dwellers. Similarly, the security challenge along the inland water routes in Bayelsa State is further aggravated by problems which has resulted from political instability among Bayelsa political elite and the crave for power among the youth bodies notably Ijaw Youth Congress (IYC). Also, the burgeoning of small arm and weapons been transported along the 
water routes by unauthorized ships and persons has fuelled crisis among political thugs, militants ,street gangsters, and mafia-like "cultists" belonging to secret societies which has culminated into battle for supremacy and has made travelling along the water routes a risky venture. Moreover, one should not forget that pirates and gangsters are often manipulated by corrupt politicians against their opponents, especially during election times. Before the elections of April 2011, for instance, sea robbers were contracted to disturb the oil industry and shows federal government or the Bayelsa and River governor can't maintain law and order. The militants, street gangsters, and mafia-like "cultists" freely traffic hard drugs and use sophisticated guns, bomb and other advance weapons to rob in inland waters to attack travellers, fishermen, traders, and residents of riverine communities around Ekeremor, Nembe, Brass, South Ijaw, and several routes. Their activities have turned business operation there to a difficult task (Akindiyo, 2014). Obed (2013) lamented a drastic drop in patronage inland waterway transport system caused by crime episodes in the routes which has hampered the development inland water transport. IMB rated the coastal region of Brass, Bonny and Lagos waters among most piracy attacked areas. They are known for high sea pirate activity which limits marine operations and makes shipping very steep due to lofty insurance cover for goods being shipped.

Canals, coastal creeks, lakes lagoons and navigable rivers make up internal waterways (Aderemo and Mogaji, 2010; Adeola and Oluyemi, 2012). The movement of goods and services along inland waterways is one of the oldest means of transporting goods and services from point to point (Fellinda, 2006). Quoting Ojile, (2006), the most economically viable, environment friendly and energy efficient cargo transport means is inland water transport. It is safe and cheap in areas where water is present. This facilitates commerce, promotes wealth creation, poverty alleviation, and creates job opportunities for youths within such regions. Welding and fabrication processes (a sector boat building industry) create employment for youths (Gray, 2006). In Nigeria, Ezenwaji (2010) noted that inland waterways transverse 20 states within Nigeria and that areas close to them contains important arable and mining lands. Gray (2006) said 48\% of Nigeria rural residents live in remote, isolated and inaccessible communities with no motorable roads and another $29 \%$ live in communities with limited services. For such people Inland Water Transport is absolutely imperative for survival and for accessing social services-education, health etc. Consequently, Ighodalo, (2009) had observed earlier that Nigeria Inland Water Transport is "untapped goldmine for investors". There is increasing awareness that Inland Water Transport is an option to road transport to connect commerce particularly in Anambra, Bayelsa, Delta, Rivers, Edo, Lagos, Cross-River AkwaIbom and Ondo States. Its environment consequence is minimal especially when one considers its noise level and energy usage.

The security challenges along the commercial water routes of Bayelsa State has made travelling unpopular due to interception of water passage amongst others; e.g. interception of oil workers from Oil multinational dedicated to distort companies operation. Igbokwe (2012) shouted about the increased piracy and armed robbery on Nigerian's Inland waterways particularly, Bayelsa waterways. He contends that robbery within Nigeria's Inland waterways domain discourages foreign investment inflow (including local businesses) needed to redevelop the economy.

With secured water routes; field investigations revealed that inland water transport, chiefly deltaic areas of Lagos, Rivers, Bayelsa and Akwa Ibom, helps rural development. Many academic scholars notable among whom are Fellinda (2006), Ojile (2006), Ezenwaji (2010), Adejare, Nwilo, and Opaluwa (2011), Achumba et al, (2013), Obed (2013), Essien and Adongoi (2015), and Okonkwo et al., (2015) did works on concerns and challenges of maritime security threats. The studies could not consider the current security issues and challenges prevailing in now Nigeria. This research emphasises current security challenges tailored to local environ of Bayelsa State affecting water transportation.

\section{MATERIALS AND METHODS}

Bayelsa is a state in Southern Nigeria in the core Niger Delta region, between Delta State and Rivers State and the capital is Yenagoa. Bayelsa State is geographically located with latitude $4^{0} 15^{\prime}$ North and latitude $5^{0} 23^{\prime}$ 'South and longitude $05^{\circ} 22^{\prime}$ west and $06^{\circ} 45^{\prime}$ East. It shares boundaries with Delta State on the North, Rivers State on the East and the Atlantic Ocean on the West and South (Figure 1) .Bayelsa State is blessed with an exceptional aligned marine surrounding ideal for transportation of goods, services and humans with other marine activities. However, most Bayelsa resources are under-utilized, less developed and a curse to the area inhabitants caused by security challenges prominent in water routes causing them to be used sparsely.

The study adopted a cross-sectional design by designing and administering questionnaire to traders, speed boat operators, marine company, fishermen or fisherwomen and other user within the selected waterfronts which cut across Bayelsa State. Also, officers and men of Joint Task Force and Maritime Workers Union were consulted. Reconnaissance survey was done using Global Positioning System (GPS) for spatial structure and route of water transport in Bayelsa State. Also, areas for questionnaire survey were delineated for the study based on major water ways in Bayelsa State that supports water transportation. The primary data was acquired from the administration of questionnaire that is made up of section A-D comprising questions that relates to socioeconomic characteristic, trip characteristic, security and operational challenges to speed boat drivers, users of inland water transport, traders and fishermen's operating within the 8 selected water front's in 3 senatorial districts of Bayelsa State. On the other hand, officers and men of maritime component of Joint Taskforce command (JTF) and maritime workers Union were sought 
International Journal of Advances in Scientific Research and Engineering (ijasre), Vol 6 (3), March-2020

and secured. Secondary source of data was acquired from relevant journals and publications, online documents and articles, map showing commercial water routes and materials from Bayelsa State Ministry of Transport, International Maritime Organisation. Seminar papers and Nigerian Maritime Administration and Safety Agency (NIMASA) annual bulletins and International Maritime Bureau (IMB) to supplement the gotten data from different categories of respondents. The questionnaire were administered using random sampling technique. Of the 363 respondents, only 320 were retrieved and used for further analysis.

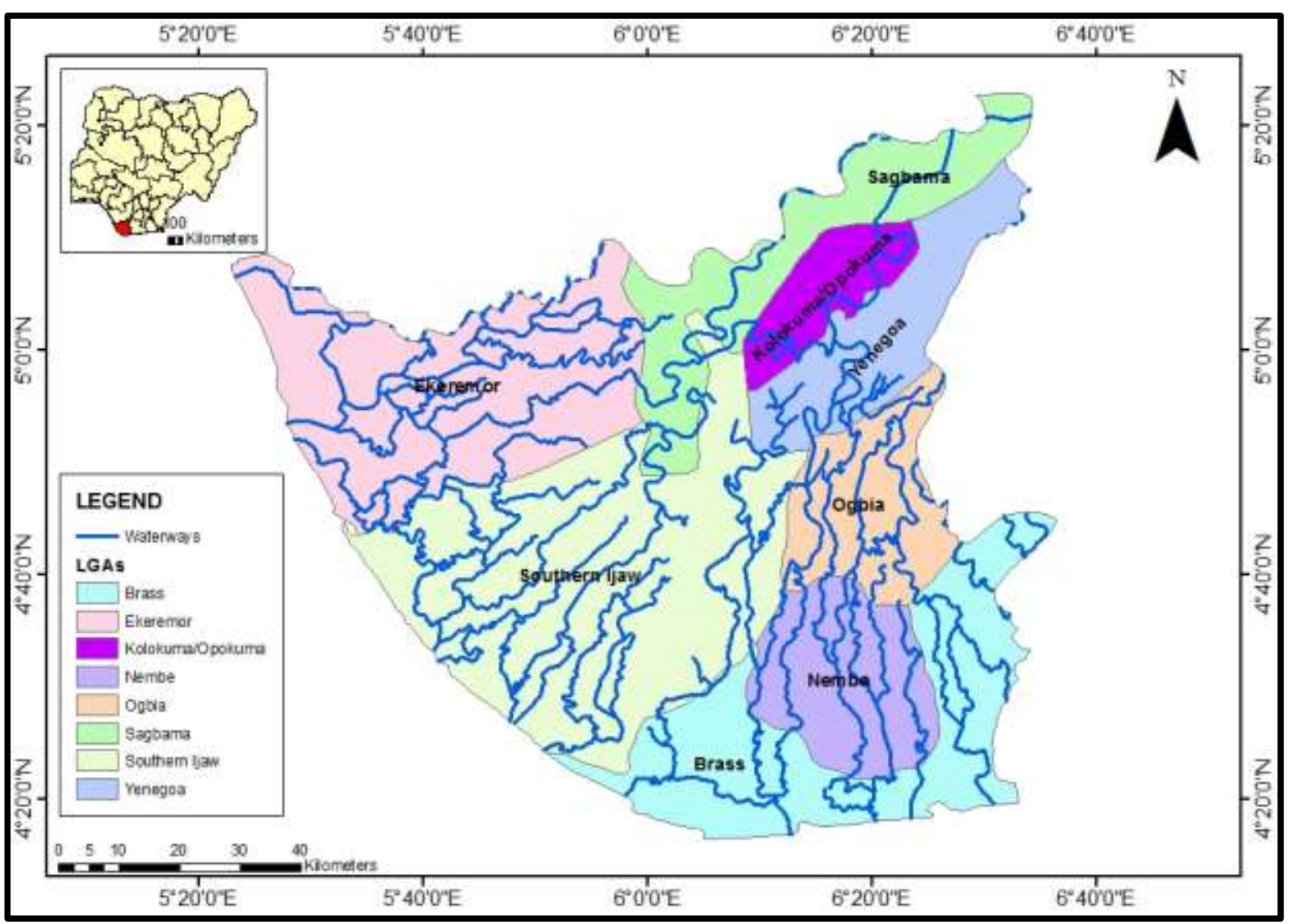

Figure 1: Map of Bayelsa State

Table 1. Selected Commercial Routes in Bayelsa State

\begin{tabular}{|l|l|l|}
\hline S/N & Waterfront & Commercial Routes \\
\hline 1 & Yenagoa & Yenagoa-Brass \\
\hline 2 & Ogbia & Ogbia-Brass \\
\hline 3 & Southern Ijaw & Oporoma -Yenagoa \\
\hline 4 & Brass & Brass-Nembe \\
\hline 5 & Nembe & Nembe-Brass \\
\hline 6 & Sagbama & Angalabiri-Yenagoa \\
\hline 7 & Kolokuma/opokuma & Kolokuma-Igbedi \\
\hline 8 & Ekeremor & Ekeremor-yenagoa \\
\hline
\end{tabular}


International Journal of Advances in Scientific Research and Engineering (ijasre), Vol 6 (3), March-2020

Table 2. Operational Characteristics of Boat Operators of Commercial Routes in Bayelsa State

\begin{tabular}{|l|l|l|l|l|l|l|}
\hline S/N & Waterfront & Commercial Routes & $\begin{array}{l}\text { Operators } \\
\text { on each } \\
\text { routes }\end{array}$ & $\begin{array}{l}\text { Time Duration of } \\
\text { trip (H) }\end{array}$ & $\begin{array}{l}\text { Seating } \\
\text { capacity }\end{array}$ & $\begin{array}{l}\text { Fare } \\
(\mathbf{N})\end{array}$ \\
\hline 1 & Yenagoa & Yenagoa-Brass & 25 & $2 \mathrm{hrs}$ & 10 & 2500 \\
\hline 2 & Ogbia & Ogbia-Brass & 5 & $1 \mathrm{hr}$ & 10 & 1500 \\
\hline 3 & Southern Ijaw & Oporoma -Yenagoa & 15 & $1 \mathrm{hr} 30 \mathrm{~min}$ & 10 & 3500 \\
\hline 4 & Brass & Brass-Nembe & 20 & $1 \mathrm{hr}$ & 10 & 2500 \\
\hline 5 & Nembe & Nembe-Brass & 20 & $1 \mathrm{hr}$ & 10 & 2500 \\
\hline 6 & Sagbama & Angalabiri-Yenagoa & 13 & $3 \mathrm{hr}$ & 10 & 2500 \\
\hline 7 & Kolokuma/Opokuma & Kolokuma-Igbedi & 6 & $30 \mathrm{~min}$ & 10 & 1500 \\
\hline 8 & Ekeremor & Ekeremor-yenagoa & 6 & $3 \mathrm{hr} 30 \mathrm{~min}$ & 10 & 2500 \\
\hline
\end{tabular}

Table 3. Questionnaire Administration

\begin{tabular}{|c|c|c|c|c|c|c|c|c|}
\hline $\mathbf{S} / \mathbf{N}$ & Waterfront & $\begin{array}{l}\text { Commercial } \\
\text { Routes }\end{array}$ & $\begin{array}{l}\text { Total } \\
\text { number of } \\
\text { Operators }\end{array}$ & $\begin{array}{l}\text { Time } \\
\text { Duration } \\
\text { of } \\
\text { Trip(h) }\end{array}$ & $\begin{array}{l}\text { Seating } \\
\text { capacity }\end{array}$ & $\begin{array}{l}\text { Frequency } \\
\text { of trip }\end{array}$ & $\begin{array}{l}\text { Fare } \\
\text { (N) }\end{array}$ & $\begin{array}{l}\text { Total } \\
\text { passengers }\end{array}$ \\
\hline 1 & Yenagoa & Yenagoa-Brass & 20 & $2 \mathrm{hrs}$ & 10 & 15 & 2500 & 150 \\
\hline 2 & Ogbia & Ogbia-Brass & 5 & $1 \mathrm{hr}$ & 10 & 7 & 1500 & 70 \\
\hline 3 & Southern Ijaw & $\begin{array}{ll}\text { Oporoma } & - \\
\text { Yenagoa }\end{array}$ & 15 & $\begin{array}{l}1 \mathrm{hr} \\
30 \mathrm{~min}\end{array}$ & 10 & 10 & 3500 & 100 \\
\hline 4 & Brass & Brass-Nembe & 25 & $1 \mathrm{hr}$ & 10 & 20 & 2500 & 200 \\
\hline 5 & Nembe & Nembe-Brass & 20 & $1 \mathrm{hr}$ & 10 & 25 & 2500 & 250 \\
\hline 6 & Sagbama & $\begin{array}{l}\text { Angalabiri- } \\
\text { Yenagoa }\end{array}$ & 13 & $3 \mathrm{hrs}$ & 10 & 4 & 2500 & 40 \\
\hline 7 & Kolokuma/Opokuma & Kolokuma-Igbedi & 6 & $30 \mathrm{~min}$ & 10 & 4 & 1500 & 40 \\
\hline 8 & Ekeremor & $\begin{array}{l}\text { Ekeremor- } \\
\text { Yenagoa }\end{array}$ & 6 & $\begin{array}{l}3 \mathrm{hrs} \\
30 \mathrm{~min}\end{array}$ & 10 & 6 & 2000 & 60 \\
\hline & Total & & 110 & & 10 & 91 & & 910 \\
\hline
\end{tabular}


International Journal of Advances in Scientific Research and Engineering (ijasre), Vol 6 (3), March-2020

Table 4. Computed sample size Proportional allocation to each commercial route's contribution to the total Operator's/User's population.

\begin{tabular}{|c|c|c|c|c|c|}
\hline S/No. & Commercial routes & $\begin{array}{l}\text { Total volume } \\
\text { of Operators }\end{array}$ & $\begin{array}{l}\text { Proportional Sample } \\
\text { Size of Operators }\end{array}$ & $\begin{array}{l}\text { Total Sample Size } \\
\text { of Route Users }\end{array}$ & Route Users \\
\hline 1 & Yenagoa-Brass & 25 & $\frac{25 \times 86}{110}=20$ & 150 & $\begin{array}{l}150 \times 277=46 \\
910\end{array}$ \\
\hline 2 & Ogbia-Brass & 5 & $\frac{5 \times 86}{110}=4$ & 70 & $\frac{70 \times 277}{910}=21$ \\
\hline 3 & Oporoma-Yenagoa & 15 & $\frac{15 \times 86}{110}=12$ & 100 & $\frac{100 \times 277=30}{910}$ \\
\hline 4 & Brass-Nembe & 20 & $\frac{20 \times 86}{110}=16$ & 200 & $\frac{200 \times 277}{910}=61$ \\
\hline 5 & Nembe-Brass & 20 & $\frac{20 \times 86}{110}=16$ & 250 & $\frac{250 \times 277}{910}=77$ \\
\hline 6 & Angalabiri-Yenagoa & 13 & $\frac{13 \times 86}{110}=10$ & 40 & $\frac{40 \times 277}{910}=12$ \\
\hline 7 & Kolokuma-Igbedi & 6 & $\frac{6 \times 86}{110}=4$ & 40 & $\frac{250 \times 277}{910}=12$ \\
\hline 8 & Ekeremor-Yenagoa & 6 & $\frac{6 \times 86}{110}=4$ & 60 & $\frac{60 \times 277}{910}=18$ \\
\hline & TOTAL & 110 & 86 & 910 & 277 \\
\hline
\end{tabular}

\section{RESULTS AND DISCUSSIONS}

\subsection{Socio-economic Characteristics of Respondents}

Table 5 outlines the socio-economic characteristics of respondents whereby the gender of respondents indicates that out of the 320 respondents, $39.7 \%$ were males, and $60.3 \%$ were females. The analysis designated that most respondents were business individuals who used the water-ways most time. Furthermore, most of these business individuals were traders who were majorly females. The age distribution analysis of respondents showed that $7.5 \%$ were in the category of $10-20$ years, $22.8 \%$ were within the bracket of 21-30 years, while 36.3\% were classified in bracket 31-40 years. Furthermore, age bracket $41-50$ were $27.8 \%$ while $5.6 \%$ of respondents were aged 50 years plus. The occupation of the respondents showed that $65.9 \%$ of respondents professed to be business men/women, $15.9 \%$ believed that they are civil servants while artisans or tradesmen/trade women accounted for $18.1 \%$ of respondents. The marital status of the respondents indicated that $29.7 \%$ of of respondents were single, $59.7 \%$ were married while $10.6 \%$ were divorced.

Table 5. Socio-Economic Characteristics of Respondents

\begin{tabular}{|l|l|l|}
\hline Gender & Frequency & Percentage (\%) \\
\hline Males & 127 & 39.7 \\
\hline Females & 193 & 70.3 \\
\hline Total & $\mathbf{3 2 0}$ & $\mathbf{1 0 0 . 0}$ \\
\hline Age Bracket (Years) & Frequency & 7.5 \\
\hline $10-20$ & 24 & 22.8 \\
\hline $21-30$ & 73 & 36.3 \\
\hline $31-40$ & 116 & 27.3 \\
\hline $41-50$ & 89 & 5.6 \\
\hline 51 and Above & 18 & $\%)$ \\
\hline
\end{tabular}


International Journal of Advances in Scientific Research and Engineering (ijasre), Vol 6 (3), March-2020

\begin{tabular}{|l|l|l|}
\hline Total & $\mathbf{3 2 0}$ & $\mathbf{1 0 0 . 0}$ \\
\hline Occupational Status & Frequency & Percentage (\%) \\
\hline Business & 211 & 65.9 \\
\hline Civil Servant & 51 & 15.9 \\
\hline Artisans & 58 & 18.2 \\
\hline Total & $\mathbf{3 2 0}$ & $\mathbf{1 0 0 . 0}$ \\
\hline Marital Status & Frequency & Percentage (\%) \\
\hline Single & 95 & 29.7 \\
\hline Married & 191 & 59.7 \\
\hline Divorce & 34 & 10.6 \\
\hline Total & $\mathbf{3 2 0}$ & $\mathbf{1 0 0 . 0}$ \\
\hline
\end{tabular}

\subsection{Spatial Analysis of Patronage among the Routes of Commercial Waterways Transport}

Of all the numerous water-ways routes identified in Bayelsa State, Table 6 showed the viable commercial routes according to respondents' patronage which indicated that $18.4 \%$ of respondents patronizes Yenagoa-Brass routes, $14.0 \%$ uses the Ogbia-Brass routes regularly while $19.2 \%$ patronizes the Oporoma-Yenagoa routes. Furthermore, Brass-Nembe routes attracted $42.0 \%$ of respondents while other routes had $6.4 \%$ patronage.

Table 6. Commercial Routes in Bayelsa State Patronage

\begin{tabular}{|c|l|c|c|}
\hline Sl.No & \multicolumn{1}{|c|}{ Commercial Routes } & Frequency & Percentage (\%) \\
\hline 1 & Yenagoa-Brass & 46 & 18.4 \\
\hline 2 & Ogbia-Brass & 35 & 14.0 \\
\hline 3 & Oporoma -Yenagoa & 48 & 42.0 \\
\hline 4 & Brass-Nembe & 105 & 6.4 \\
\hline 5 & Others & 16 & 100.0 \\
\hline
\end{tabular}

\subsection{Types of Security Challenges along the Commercial Waterways in Bayelsa}

From Table 7 outlines waterways passengers' responses on the types of security challenges along the commercial waterways in Bayelsa State. Piracy/sea robbery, cultism, smuggling, kidnapping and illegal oil bunkering were identified by the passengers as security challenges common to Bayelsa waterways. These were confirmed as these items returned with a mean number greater than criterion mean 2.5. Other types of security challenges like rape, drug trafficking, pipeline vandalism, ethno-political conflict and community conflict were said not to pose any significant challenges to the waterway security as their returned mean values are less than the criterion mean of 2.5. From Table 8, that outlines waterways operators' responses on the types of security challenges in Bayelsa State; piracy/ sea robbery, cultism, smuggling, kidnapping and illegal oil bunkering were identified by the operators as the major types of security challenges that are common in the Bayelsa waterways. These were confirmed as these items returned with a mean values greater than the criterion mean of 2.5. Other types of security challenges like rape, drug trafficking, pipeline vandalism, ethno-political conflict and community conflict were said not to pose any significant challenges to the waterway security as their returned mean values are less than the criterion mean of 2.5 . 
International Journal of Advances in Scientific Research and Engineering (ijasre), Vol 6 (3), March-2020

Table 7. Types of security challenges identified by the Passengers

\begin{tabular}{|l|l|l|l|l|l|l|}
\hline Challenges & N & Min & Max & Mean & S.D. & Resolve \\
\hline Piracy/Sea robbery & 250 & 1 & 4 & 3.38 & 0.98 & Accept \\
\hline Cultism & 250 & 1 & 4 & 3.27 & 0.92 & Accept \\
\hline Rape & 250 & 1 & 4 & 2.36 & 1.13 & Reject \\
\hline Smuggling & 250 & 1 & 4 & 3.18 & 0.88 & Accept \\
\hline Drug Trafficking & 250 & 1 & 4 & 2.43 & 0.92 & Reject \\
\hline Pipelines Vandalism & 250 & 1 & 4 & 2.43 & 1.91 & Reject \\
\hline Kidnapping & 250 & 1 & 4 & 3.04 & 0.93 & Accept \\
\hline Ethno-political & 250 & 1 & 4 & 2.02 & 0.98 & Reject \\
\hline Illegal Bunkering & 250 & 1 & 4 & 3.29 & 0.90 & Accept \\
\hline Community conflict & 250 & 1 & 4 & 2.28 & 1.33 & Reject \\
\hline
\end{tabular}

Table 8. Nature and types of security challenges (Operators Responses)

\begin{tabular}{|l|l|l|l|r|l|l|}
\hline \multicolumn{1}{|c|}{ Item } & \multicolumn{1}{|c|}{ N } & \multicolumn{1}{c|}{ Min } & \multicolumn{1}{c|}{ Max } & \multicolumn{1}{c|}{ Mean } & S.D. & Resolve \\
\hline Piracy/Sea robbery & 70 & 1 & 4 & 3.42 & 0.88 & Accept \\
\hline Cultism & 70 & 1 & 4 & 2.80 & 1.11 & Accept \\
\hline Rape & 70 & 1 & 4 & 2.18 & 0.94 & Reject \\
\hline Smuggling & 70 & 1 & 4 & 2.6 & 0.72 & Accept \\
\hline Drug Trafficking & 70 & 1 & 4 & 2.11 & 1.19 & Reject \\
\hline Pipelines Vandalism & 70 & 1 & 4 & 1.88 & 1.66 & Reject \\
\hline Kidnapping & 70 & 1 & 4 & 2.98 & 0.93 & Accept \\
\hline Ethno-political & 70 & 1 & 4 & 2.32 & 0.71 & Reject \\
\hline Illegal Bunkering & 70 & 1 & 4 & 2.92 & 0.88 & Accept \\
\hline Community conflict & 70 & 1 & 4 & 2.25 & 1.88 & Reject \\
\hline
\end{tabular}

\subsection{Locations along the routes that are prone to security attacks along commercial water routes in Bayelsa State}

From Table 9, the routes which are prone to attack according to passengers' responses are Oporoma-Yenagoa route, Brass-Nembe route and Yenagoa-Brass route. The Ogbia-Brass route was deemed as been safe according to the passengers plying the route sampled in the research. From the operators' perspective, Table 10 displays the routes susceptible to attacks. Oporoma-Yenagoa route, Brass-Nembe route and Yenagoa-Brass route were said to experience regular attacks while Ogbia-Brass route is a safe route for travel.

Table 9: Route prone to attacks by Passengers

\begin{tabular}{|l|c|c|c|c|c|c|}
\hline \multicolumn{1}{|c|}{ Routes } & N & Min & Max & Mean & S.D & Resolve \\
\hline Ogbia-Brass & 21 & 1 & 4 & 2.4 & 1.4 & Reject \\
\hline Oporoma -Yenagoa & 45 & 1 & 4 & 2.9 & 0.87 & Accept \\
\hline Brass-Nembe & 138 & 1 & 4 & 3.1 & 0.89 & Accept \\
\hline Yenagoa-Brass & 46 & 1 & 4 & 2.9 & 0.76 & Accept \\
\hline & 250 & & & & & \\
\hline
\end{tabular}


International Journal of Advances in Scientific Research and Engineering (ijasre), Vol 6 (3), March-2020

Table 10. Route prone to attacks (Operators Response)

\begin{tabular}{|l|c|c|c|c|c|c|}
\hline Routes & N & Min & Max & Mean & S.D & Resolve \\
\hline Ogbia-Brass & 6 & 1 & 4 & 2.0 & 1.76 & Reject \\
\hline Oporoma -Yenagoa & 12 & 1 & 4 & 2.9 & 0.78 & Accept \\
\hline Brass-Nembe & 32 & 1 & 4 & 3.3 & 0.93 & Accept \\
\hline Yenagoa -Brass & 20 & 1 & 4 & 3.4 & 0.91 & Accept \\
\hline & 70 & & & & & \\
\hline
\end{tabular}

\subsection{Space-time analysis of incidence of security challenges along commercial water routes in Bayelsa State}

Time of travel according to passengers plying the commercial waterways in Bayelsa is outlined in Table 11. The main periods of travel are $6 \mathrm{am}-9 \mathrm{am}, 9 \mathrm{am}-12 \mathrm{pm}, 12 \mathrm{pm}-3 \mathrm{pm}$, and $3 \mathrm{pm}-6 \mathrm{pm}$. Most passengers travel in the morning, afternoon and evening. However, night travel is not a common thing among the passengers. Furthermore, from Table 12, operators plying the waterways indicated that the periods of $6 \mathrm{am}-9 \mathrm{am}, 9 \mathrm{am}-12 \mathrm{pm}, 12 \mathrm{pm}-3 \mathrm{pm}$, and $3 \mathrm{pm}-6 \mathrm{pm}$ are the periods that their service is mostly needed and rendered. The period of $6 \mathrm{pm}-9 \mathrm{pm}$ travel time returned with a rejected verdict on the analysis of their responses.

Table 11. Time of Travel (Passengers Response)

\begin{tabular}{|l|l|l|l|l|l|l|}
\hline Item & N & Min & Max & Mean & S.D & Resolve \\
\hline $6 \mathrm{am}-9 \mathrm{am}$ & 250 & 1 & 4 & 2.97 & 1.4 & Accept \\
\hline $9 \mathrm{am}-12 \mathrm{pm}$ & 250 & 1 & 4 & 3.29 & 0.88 & Accept \\
\hline $12 \mathrm{pm}-3 \mathrm{pm}$ & 250 & 1 & 4 & 3.30 & 0.78 & Accept \\
\hline $3 \mathrm{pm}-6 \mathrm{pm}$ & 250 & 1 & 4 & 3.40 & 1.12 & Accept \\
\hline $6 \mathrm{pm}-9 \mathrm{pm}$ & 250 & 1 & 4 & 2.40 & 2.20 & Reject \\
\hline
\end{tabular}

Table 12. Time of Travel (Operators Response)

\begin{tabular}{|l|c|c|c|c|c|c|}
\hline Item & N & \multicolumn{1}{l|l}{ Min } & Max & Mean & S.D & Resolve \\
\hline $6 \mathrm{am}-9 \mathrm{am}$ & 70 & 1 & 4 & 3.13 & 0.92 & Accept \\
\hline $9 \mathrm{am}-12 \mathrm{pm}$ & 70 & 1 & 4 & 2.90 & 0.96 & Accept \\
\hline $12 \mathrm{pm}-3 \mathrm{pm}$ & 70 & 1 & 4 & 3.33 & 1.19 & Accept \\
\hline $3 \mathrm{pm}-6 \mathrm{pm}$ & 70 & 1 & 4 & 2.99 & 2.11 & Accept \\
\hline $6 \mathrm{pm}-9 \mathrm{pm}$ & 70 & 1 & 4 & 2.31 & 2.91 & Reject \\
\hline
\end{tabular}

Table 13 outlines responses of passengers to the period when attacks are common. Evening and night were the periods when the waterways experiences security challenges. The boat operators on the identified routes also identified evening and night period as the time where most attacks occurs as displayed in Table 14. 
International Journal of Advances in Scientific Research and Engineering (ijasre), Vol 6 (3), March-2020

Table 13. Time prone to Attack (Passengers Response)

\begin{tabular}{|l|c|l|l|l|l|l|}
\hline Item & N & Min & Max & Mean & S.D & Resolve \\
\hline Morning & 250 & 1 & 4 & 2.16 & 1.4 & Reject \\
\hline Afternoon & 250 & 1 & 4 & 2.40 & 0.91 & Reject \\
\hline Evening & 250 & 1 & 4 & 3.10 & 1.66 & Accept \\
\hline Night & 250 & 1 & 4 & 3.06 & 2.61 & Accept \\
\hline
\end{tabular}

Table 14. Time prone to Attack (Operators Response)

\begin{tabular}{|l|c|c|c|c|c|c|}
\hline Item & N & Min & Max & Mean & S.D & Resolve \\
\hline Morning & 70 & 1 & 4 & 1.89 & 1.90 & Reject \\
\hline Afternoon & 70 & 1 & 4 & 2.27 & 1.23 & Reject \\
\hline Evening & 70 & 1 & 4 & 3.12 & 0.99 & Accept \\
\hline Night & 70 & 1 & 4 & 3.12 & 1.77 & Accept \\
\hline
\end{tabular}

\subsection{Causes of Security Challenges}

Reviewing result from Table 15 which analyses passengers' perceptions on the causes of waterways security challenges, it can be said that unemployment, underdevelopment, illiteracy, lack of adequate security and poverty were perceived by passengers as causes of insecurity on Bayelsa waterways. The notions that mismanagement of natural resources and political interference are causes of insecurity in the waterways were rejected.

Table 16 displays the responses of operators on the question of causes of insecurity on the waterways. Unemployment, underdevelopment, illiteracy, lack of adequate security and poverty were accepted as notable causes while political interference and natural resources mismanagement were rejected.

Table 15: Causes of security challenges (Passengers' responses)

\begin{tabular}{|l|l|l|l|l|l|l|}
\hline Item & N & Min & Max & Mean & S.D. & Resolve \\
\hline Unemployment & 250 & 1 & 4 & 3.15 & 0.93 & Accept \\
\hline Underdevelopment & 250 & 1 & 4 & 3.14 & 0.91 & Accept \\
\hline Illiteracy & 250 & 1 & 4 & 3.09 & 0.88 & Accept \\
\hline Lack of security & 250 & 1 & 4 & 3.39 & 1.32 & Accept \\
\hline Natural resources mismanagement & 250 & 1 & 4 & 2.38 & 0.97 & Reject \\
\hline Political interference & 250 & 1 & 4 & 2.40 & 3.05 & Reject \\
\hline Poverty & 250 & 1 & 4 & 3.39 & 1.55 & Accept \\
\hline
\end{tabular}

Table 16: Causes of security challenges (Operators' responses)

\begin{tabular}{|l|l|l|l|l|l|l|}
\hline Item & N & Min & Max & \multicolumn{1}{l|}{ Mean } & S.D. & Resolve \\
\hline Unemployment & 70 & 1 & 4 & 3.29 & 1.66 & Accept \\
\hline Underdevelopment & 70 & 1 & 4 & 3.41 & 0.93 & Accept \\
\hline Illiteracy & 70 & 1 & 4 & 2.81 & 0.71 & Accept \\
\hline Lack of security & 70 & 1 & 4 & 3.49 & 0.88 & Accept \\
\hline
\end{tabular}


International Journal of Advances in Scientific Research and Engineering (ijasre), Vol 6 (3), March-2020

\begin{tabular}{|l|l|l|l|r|l|l|}
\hline Natural resources mismanagement & 70 & 1 & 4 & 2.44 & 0.99 & Reject \\
\hline Political interference & 70 & 1 & 4 & 2.25 & 4.66 & Reject \\
\hline Poverty & 70 & 1 & 4 & 3.15 & 1.87 & Accept \\
\hline
\end{tabular}

\subsection{Factors affecting Inland Water Transportation in Bayelsa State}

Table 17 presents the passengers' responses on the various factors affecting water transportation in Bayelsa State. Cost and availability of fuel, multi-designated authorities, lack of navigational aid, decrease in water level and security concerns are factors affecting water transportation in Bayelsa State. Table 18 presents the operators' responses on the various factors affecting water transportation in Bayelsa State. Cost and availability of fuel, multi-designated authorities, lack of navigational aid, decrease in water level and security concerns are the major factors affecting water transportation in Bayelsa State.

Table 17. Factors affecting Inland Water Transportation in Bayelsa State (Passenger Responses)

\begin{tabular}{|l|l|l|l|c|c|c|}
\hline Item & N & Min & Max & Mean & S.D. & Resolve \\
\hline Cost and availability of fuel & 250 & 1 & 4 & 3.02 & 0.93 & Accept \\
\hline Multi-designated authorities & 250 & 1 & 4 & 3.01 & 0.91 & Accept \\
\hline Lack of Navigational aid & 250 & 1 & 4 & 3.26 & 0.88 & Accept \\
\hline Decrease in water level & 250 & 1 & 4 & 2.63 & 1.32 & Accept \\
\hline Security concern & 250 & 1 & 4 & 3.38 & 0.97 & Accept \\
\hline
\end{tabular}

Table 18. Factors affecting Inland Water Transportation in Bayelsa State (Operators Responses)

\begin{tabular}{|l|c|c|c|c|c|c|}
\hline Item & N & Min & Max & Mean & S.D. & Resolve \\
\hline Cost and availability of fuel & 70 & 1 & 4 & 3.31 & 1.66 & Accept \\
\hline Multi-designated authorities & 70 & 1 & 4 & 3.35 & 0.93 & Accept \\
\hline Lack of Navigational aid & 70 & 1 & 4 & 3.47 & 0.71 & Accept \\
\hline Decrease in water level & 70 & 1 & 4 & 2.62 & 0.88 & Accept \\
\hline Security concern & 70 & 1 & 4 & 3.40 & 0.99 & Accept \\
\hline
\end{tabular}

\subsection{Relationship between Security Challenges and the patronage of Inland Waterway Transportation}

From Chi-square test analysis in Table 19 using 0.05 alpha level and a degree of freedom (df) of 3. The chi-test value $\left(\mathrm{X}^{2}\right)$ is 30.2127 and $p$-value is 0.000001245 . Since $X^{2}=30.21$ is greater than the critical value $=7.815 ; p<0.005$, the null hypothesis is rejected. Hence, there is a statistical significant relationship between security challenges and the patronage of inland waterways transportation in Bayelsa State.

Table 19: Relationship between security challenges and patronage of Inland Waterway

\begin{tabular}{|c|c|c|c|c|}
\hline Item & $\mathbf{S A}$ & $\mathbf{A}$ & $\mathbf{D}$ & SD \\
\hline Security challenges & 164 & 103 & 33 & 20 \\
\hline Does security challenges affect Patronage & 128 & 78 & 69 & 45 \\
\hline $\mathrm{X}^{2}$ & \multicolumn{4}{|c|}{30.2127} \\
\hline Degree of Freedom (df) & \multicolumn{4}{|l|}{3} \\
\hline p-value & \multicolumn{4}{|c|}{0.000001245} \\
\hline Critical value & \multicolumn{4}{|l|}{7.815} \\
\hline
\end{tabular}


International Journal of Advances in Scientific Research and Engineering (ijasre), Vol 6 (3), March-2020

\subsection{Relationship between Frequency of Security Threat and Number of Period of Policing}

From the result of the Chi-square test analysis in Table 20, using 0.05 alpha level and a degree of freedom (df) of 3. The chi-test value $\left(X^{2}\right)$ is 206.544 and $p$-value is 0.000001324 . Since $X^{2}=206.544$ is greater than the critical value $=7.815 ; p<0.005$, the null hypothesis is therefore rejected. Thus there is a statistical significant relationship security threat on period of policing and period of non-policing.

Table 20: Relationship between frequency of security threat and Number of Period of Policing

\begin{tabular}{|c|c|c|c|c|}
\hline Item & $\mathbf{S A}$ & $\mathbf{A}$ & $\mathbf{D}$ & SD \\
\hline Security threat period of policing & 23 & 74 & 56 & 167 \\
\hline Security threat period of non-policing & 175 & 78 & 29 & 38 \\
\hline $\mathrm{X}^{2}$ & \multicolumn{4}{|l|}{206.544} \\
\hline Degree of Freedom (df) & \multicolumn{4}{|l|}{3} \\
\hline p-value & \multicolumn{4}{|c|}{0.000001324} \\
\hline Critical value & \multicolumn{4}{|l|}{7.815} \\
\hline
\end{tabular}

\section{DISCUSSION OF FINDINGS}

Findings showed that of the several routes identified, Nembe-Brass route, Oporoma-Yenagoa route, Yenagoa-Brass route and Ogbia-Brass route are the most commercially viable routes. High number of waterway routes and the high patronage they experience confirms the assertion of Ojile (2006) which states that water transportation offers safer and cheaper rates in areas where water exist naturally. Piracy/sea robbery, cultism, smuggling, kidnapping and illegal oil bunkering were identified as the major types of security challenges that are common in the Bayelsa waterways. This finding conforms to the study of Ogundiya (2009) which identified kidnapping, cultism, piracy as security menaces that have bedeviled the Niger-Delta region of Nigeria. Illegal oil bunkering according to Garuba, (2010) is also a major security threat in the region. According to Uadiale (2011), piracy is increasing along the coast and waterways in Nigeria; this affirms the findings of this study. From four commercially viable routes used in this study, Oporoma-Yenagoa, Nembe-Brass and Yenagoa-Brass Routes are the major routes prone to attacks. This corroborates the findings of Ochai (2013) which reported that Bayelsa waterways is the most often attacked water routes in Nigeria. Ochai (2013) further claimed that Nembe and Brass waterways experienced more pirate attacks than any other routes in Bayelsa State. In term of spatio-temporal analysis of security incidence in various sampled routes, evening and night periods experience more attacks than all other periods. Most of the attackers use darkness as cover when perpetrating their heinous crime. Also, lack of adequate security at that time encourages frequent attacks. Unemployment, underdevelopment, illiteracy, lack of adequate security and poverty were alleged to be the causes of insecurity on Bayelsa waterways. This affirms various workers' findings like International Labour Office (ILO) (2009) who argued that poverty is the greatest source of civil strife in Nigeria; Mensah and Enu-Kwesi (2019) who said pollution of the environment deprives the populace their legal means of livelihood thereby forcing some to take-up illegal means of livelihood. Cost and availability of fuel, lack of navigation aid, decrease in water level, multi-designated authorities and security concern were identified as the major factors affecting water transportation in Bayelsa State. The study has revealed that there is a statistical significant relationship between security challenges and the patronage of inland waterway transportation. It aligns with the findings of IMB (2012) which states that incessant attacks by pirates and robbers on travellers along Nembe, Brass, and Yenagoa waterways have made sea business operation more challenging than expected.

\section{CONCLUSION AND RECOMMENDATIONS}

The study has concluded that Nembe-Brass route, Oporoma-Yenagoa route, Yenagoa-Brass route and Ogbia-Brass route are commercially viable routes making them enticing routes both for transportation and pirates and robbers attacks. Also, piracy/sea robbery, cultism, smuggling, kidnapping and illegal oil bunkering were identified as the major types of security challenges that are common in the Bayelsa waterways. However, evening and night period experience more attacks than all other period of the day. Unemployment, underdevelopment, illiteracy, lack of adequate security and poverty, cost and availability of fuel, lack of navigation aid, decrease in water level, multi-designated authorities were the main causes of insecurity on Bayelsa waterways. It is recommended that the commercial water transport routes in Bayelsa State should be constantly dredged intermittently by State government to enable bigger ships ply the routes thereby enabling more commercial activities; both Federal, State, Local governments and Inland waterways transport regulatory bodies should make available navigational aid and adequate security along the routes to avert any variety of Security Challenges; locations along the routes that are prone to security attack could be 
transmute to security check points mounted by Joint security team having of the Nigeria Air force, Army, Navy, Marine Police and the State Security Service; both the Federal, State government and Regulatory authority should ponder the recruitment of youth bodies and ex-militants into the joint taskforce and surveillance team because of involvement of their ability to identify the pirates' know time of operation, the creeks and area geography; youth employment should be adequately provided; proliferation and illegal custody of firearms through cult/gang doings should be stemmed by those saddled with the responsibility of securing the environment; and those arrested with arms should be prosecuted to deter others.

\section{REFERENCES}

1. Achumba, I. C., Ighomereho, O. S., \& Akpan-Robaro, M. O. M. (2013). Security Challenges in Nigeriaand the Implications for Business Activities and Sustainable Development. Journal of Economics and Sustainable Development, 4(2), 79-99.

2. Aderemo, A. J. and Mogaji. A. (2010). Rural Transportation of Public facilities in Nigeria: A Case of Edu Local Government Area of kwara State‘. Journal of Human Ecology 29(3), 171-179.

3. Akindiyo, O (2014). Security challenge and development in Nigeria: leadership to the rescue? International Journal of Academic Research in Public Policyand Government 1(1): 49-5

4. Essien B. S. and Adongoi, T. (2015). Sea Piracy and Security Challenges of Maritime Business Operation in Bayelsa State, Nigeria: An Empirical Study. International Journal of Humanities and Social Science, 5(2): 213-221

5. Ezenwaji, E. E. (2012). Constraints on Effective Water Transportation in Some Riverine Communities of Old Anambra L.G.A., Anambra Statell. A Paper Delivered at the 2010 Rural Development Seminar, Rural Transportation in Nigeria. Imo State University, Owerri, 31st March to 1st April, 2010.

6. Fellinda, L. (2006). World‘s Water Transport needs further Development. Transport and Development 1, 68-72.

7. Garuba, D. S. (2010). Trans-Border Economic Crimes, Illegal Oil Bunkering and Economic Reforms in Nigeria, Policy Brief Series, No. 15, October, Global Consortium on Security Transformation.

8. Igbokwe, M. I. (2012). Recent Development in Nigeria Maritime Law and Practice: Piracy and unlawful Acts at sea. 12thMaritime seminar for Judges.5th-7thJune, Abuja.

9. Ighodalo, C.A. (2009). Transport Infrastructure and Economic Growth in Nigeria. Revised Paper Submitted for Presentation at the First International Conference on Transport Infrastructure (ICTI 2008), Beijing, China. April 24-26, 2008.

10. IMB, (2009). Piracy and armed robbery against ships: Report for the period 1, January -31 December 2008, London: IMB.

11. International Labour Office (ILO) (2005). Gender, Poverty and Employment: Turning Capabilities into Entitlements, Geneva, International Labour Organization.

12. Mensah J. \& Enu-Kwesi F. (2019). Implications of environmental sanitation management for sustainable livelihoods in the catchment area of Benya Lagoon in Ghana, Journal of Integrative Environmental Sciences, 16:1, 23-43, DOI:10.1080/1943815X.2018.1554591

13. Obed, B. C. (2013). A Critical Assessment of the Inland Waterways Operations and Management of the Development of Nigerian Maritime Industry. Greener Journal of Environmental Management and Public Safety 2(2), 99-17.

14. Ochai, P. (2013). Owners of fishing trawlers want the FederalGovernment to save their business from the increasing attacks they encounter from sea pirates. Thisday Newspapers, January 7.

15. Ogundiya I.S. (2009). Domestic Terrorism and Security Threats in the Niger Delta Region of Nigeria. J Soc Sci, 20(1): $31-42$

16. Ojile, M. O. (2006). Draft Report of the Socio-Economic Characteristics for the Idealization of the Port Harcourt Warri Roads Submitted to Messer allots Nigeria. Limited on behalf of the Federal Ministry of Works, Abuja 1:60

17. Okonkwo R.I, P. Ndubuisi-Okolo and T. Anagbogu (2015). Security Challenges and the Implications for Business Activities in Nigeria: A Ctritical Review. Journal of Policy and Development Studies, 9(2): 157-168

18. Uadiale, M., (2012). Maritime piracy in contemporary Africa. Africa strategic forum: A Journal in the Centre of Strategic and Development Studies. Ekpoma: Ambrose Ali University. (In press) 2012. [Accessed 20 Nov. 2013] 